\title{
The Influence of Pedagogigal Competence, Emotional Intelligence and Task Commitment on Teaching Effectiveness at Senior High School: Case study at SMA Muhammadiyah of Palembang
}

\author{
Herasni, Nur Hartati Fuad, Maruf Akbar \\ $\left\{\right.$ mp14s3@mahasiswa.unj.ac.id $\left.{ }^{1}\right\}$
}

Jakarta State University ${ }^{1,2,3}$

\begin{abstract}
This study aims to obtain information about the effect of Pedagogical Competence, Emotional Intelligence And Commitment Task to The Effectiveness of Teaching At High School Teachers Muhammadiyah City Palembang. This research is an associative quantitative research, The research was conducted by using survey method with path analysis in hypothesis testing. In this study, the population in this study as many as 302 respondents, and a sample of 111 respondents are selected by using random sampling. Research is focused onfour aspects; Pedagogic Competence, Emotional Intelligence, Task Commitment and Teaching Effectiveness. The results of the analysis are (1) there is a positive direct effect of Pedagogic Competence on Teaching Effectiveness, (2). there is a positive direct effect ofEmotional Intelligence on Teaching Effectiveness, (3) there is a positive direct effect of Task Commitment on Teaching Effectiveness, (4) there is a positive direct effect of Pedagogic Competence on task commitment, (5) there is a positive direct effect of emotional intelligence on task commitment, (6) there is a positive direct effect of Pedagogic Competence on Emotional Intelligence.
\end{abstract}

Keywords: Pedagogic Competence, Emotional Intelligence, Task Commitment, and Teaching Effectiveness.

\section{Introduction}

\subsection{Background of the Study}

Nowadays, teacher professional become an important topic to discuss since it appears in the public as a result of qualified educational. Moreover, it is related with positive response from the government by established teacher as a profession in December 2, 2004 and decreed laws no 14 year 2005 about Teacher and Lecturer. Teacher as a component personnel in the School is expected to show the quality in every performance to achieve the purpose ad a teacher, so teacher is demanded to have effectiveness teaching to solve several problem in educational process.

This result is taken from the headmaster of Muhammadiyah Senior High School in Palembang during teaching process. Furthermore, certified teacher and permanent teacher must be fulfilled 24 hours in a week and another teacher must be accepted these condition. In 
fact, certified teacher is not fulfilled the duty yet, especially teacher from the subject of the study, so they are teaching in equal School in order to fulfill the duty. In relation with those problems about the effectiveness teaching in 9 Muhammadiyah senior High School in Palembang, the result is there is no balancing between teacher and accreditation. Thus, it is caused the integration between each component, plan, and implementation are not working as expected. The problem about Teacher competency is determined in solving the problem that is related with teacher ability through founding, education, and professionalism developing from several problems such as curriculum, subject, and device. These become a basic step for the researcher related with teacher effectiveness in educational institution, in Muhammadiyah Palembang.

Further, relates with the fact above, initial data is collected by the researcher from several Cases in Muhammadiyah Senior High School Palembang that is related with teaching effectiveness, Pedagogical competence, emotional intelligence, and task commitment. In relation with the previous data, there are several problems that appear, such as, lack of sources for students, and the usage of learning process media is not professional. Some of the teachers are less developed in the subject of the study. The subject itself is delivered by speech and classical method. So, teaching effectiveness of the teacher must have pedagogical competence in mastering student's characteristic, theory, principles, curriculum development, and learning activity.

Moreover, a teacher must have emotional intelligence to feel and to create empathy and emotion. It is also related with teacher commitment in order to create effective learning process in the School. Professional teacher have personal, intellectual, morality, spiritual responsibilities within learning and teaching process interaction in order to help the students achieved their goal. Indeed, the teacher is not only demanded to have ability to teach but also the teacher must have ability to handle all the students abilities and skill with an appropriate method and media. The teacher is giving less motivation to the students for asking a question or giving a comment during the learning process. Therefore, another problem appears about student's reward and punishment during the learning process is not maximal, such as; giving the students homework as their punishment can be said that it is not a proper way to discipline them. Those are caused because of less motivation of teacher performance, whereas external factors are affected less behavior commitment.

In order to prove performance effectiveness of the teacher pedagogical competence, emotional intelligence, and task commitment are needed. Those assumptions will give positive effect toward task effectiveness of the teacher. Otherwise, several factor, such; pedagogical competence, emotional intelligence, and task commitment become a serious concern from educational institution and the researcher to reveal the relation between each variable.

\subsection{Identification of the Problem}

Identification of the problem appears in the initial research, as follows; lower effectiveness of teacher performance because of teacher classification, less commitment, and supervision from the headmaster toward the teacher, media for learning process is not maximal, several infrastructure and facilitates in the library is not maximal, there is no belonging toward the school, minimum knowledge about profession educational, and undeveloped curriculum. 


\subsection{Limitation of the problem}

In relation with Identification of the problem, there are a lot of factors that are affected teaching effectiveness of Muhammadiyah senior High School Palembang teacher. This research is limited with 4 variable, that are; Competence as variable (X1), Emotional Intelligence as variable (X2), Task Commitment as variable (X3), and teaching effectiveness as variable $(\mathrm{Y})$.

\subsection{Formulation of the Problem}

Based on Identification and Limitation of the problem that are described in this research with several points as follows;

1. There is Direct effect of pedagogical competence (X1) toward teaching effectiveness (Y)

2. There is direct effect of pedagogical competence (X1) toward emotional intelligence (X2)

3. There is direct effect of pedagogical competence (X1) toward task commitment (X3)

4. There is direct effect of emotional intelligence (X2) toward teaching effectiveness (Y)

5. There is direct effect of emotional intelligence (X2) toward task commitment (X3)

6. There is direct effect of task commitment (X3) toward teaching effectiveness (Y)

\section{Theory}

\subsection{Basic Theory}

\section{Teaching Effectiveness}

Effectiveness is a way to get all the purpose and target all activities and programs. Liu states that effective teaching means promoting the student"s development to achieve the teaching goal by enhancing teacher"s teaching efficiency". He states that although for a simple purpose, but for reach the purpose is not an easy proccess. Further, in performing the duty, a teacher must be mastering all knowledge about the subject and how to teach the subject in effective and colaborativre way in order to help the students.

\section{Pedagogical Competence}

According to Jinga from Ryegard [1] Michael Olalekan Olatunji in Journal Pahrudin (2016:336) states that competence implies that teachers from the purpose and the current framework through continuous teaching development and personal profesionalism development, support and facilitate the students' learning proccess in appropriate way. Pedagogical competence also reflects teacher competence in colaboration, comprehensive opinion and contribution to develope pedagogy for High education.

Similarly, [2], "competencies: skills, knowledge, aptitudes, and other characteristics of people that lead to superior performance."

\section{Emotional Intelligence}

Sharif Mustaffa, et,al state that emotional intelligence is a professional indicator that shows illustration from counseling service relates with professional identity. However, another problem that is detected is a perception that has the lack of counseling service because of less 
emotional intelligence, less counseling skill, and personal quality between counselor include middle School counselor.

\section{Task Commitment}

States Organization commitment is an attitude that reflects as far as an individual know the organization [3]. An individual has high commitment probably will be seen as the real member of organization.

Park explains that teacher commitment is spiritual power come from inside and outside about the duty which is giving effect toward teacher's behaviour about responsibility and responsive to Knowledge and technology development [4].

\subsection{Relevance Research}

Asep Achadiat Sudrajat in his research states "Commitment profession of SMA TP correlational between inovation and motivation achievement teacher with commitment profession lecturer in SMA TP Manajemen Program Excalation Quality based on Campus in Bogor regency", it is proved that teacher inovative has positive relation with commitment profession of the lecture. It means that powerful achievement motivation give a positive impact for commitment profession of teacher qualitu, with coeficient correlation ry $2=$ 0.99734 and ry $12=0.0995$.

Furthermore, relevance research about the self learning effect toward pedagogical competence by [5], The research entitle, "Leadership, Emotional Intelligence and Employee Engagement: Creating a Pedagogic Competence" The result states that there is a connection between leadership, emotional intelligence, and employee commitment where are the third components will produce pedagogical competence.

\subsection{Hypothesis of the research}

1. There is direct effect of pedagogical competence toward task effectiveness of the teacher.

2. There is direct effect of pedagogical competence toward emotional intelligence.

3. There is direct effect of pedagogical competence toward task commitment.

4. There is direct effect of emotional intelligence toward task effectiveness of the teacher.

5. There is direct effect of emotional intelligence toward task commitment.

6. There is direct effect of task commitment toward task effectiveness of teacher's task.

\section{Methodology Of The Research}

\subsection{Date and Place of the research}

This research is held in Muhammadiyah Senior High School in Palembang. The research begins from February 2017 untill March 2017. 


\subsection{Methodology of the research}

This research is used survey as methodology of the research. While, based on reality characteristic, this research is used quantitative methodology, because the data can be classified as concreted, observed, and measured.

Variable relation is a relation that is caused as causal between dependent variable toward independent variable. Independent variable such as: (1) Pedagogical competence (X1), (2) Emotional Intelligence (X2), (3) Task Commitment (X3), and dependent variable is (4) Teaching Effectiveness (Y).

Based on the basic of axiom about generalization possibility and value, it can be concluded that this research has independent value. The characteristic in this quantitative research used paradigm design, path analysis to show causality relation includes $\mathrm{X} 1$ affected Y, X1 affected X3, X1 affected X2, X2 affected Y, X2 affected X3, X3 affected teaching effectiveness of the teacher $(Y)$.

$\mathrm{X}_{1}$

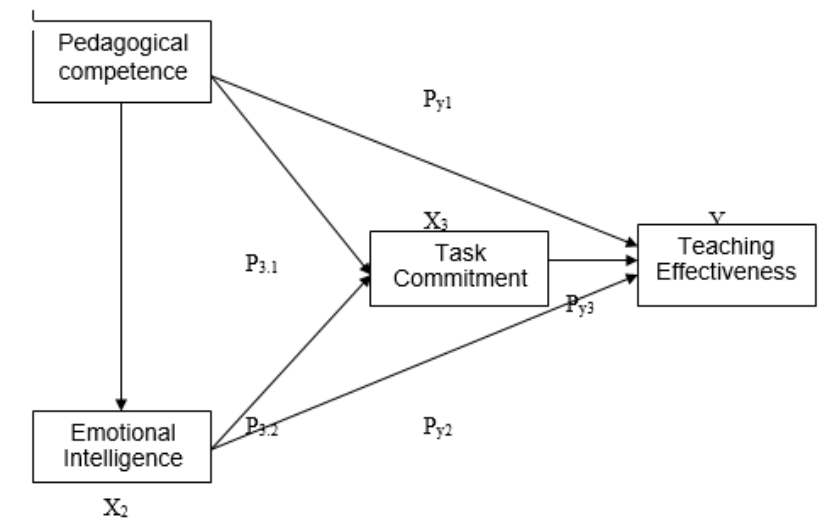

Fig. 1. Constellation Model between Variable of the Research

Constellation model from illustration 3.1 can be described as follows:

$$
\mathrm{Y}=\mathrm{P}_{\mathrm{y} 1} \mathrm{X}_{1}+\mathrm{P}_{\mathrm{y} 2} \mathrm{X}_{2}+\mathrm{P}_{\mathrm{y} 3} \mathrm{X}_{3},=\mathrm{P}_{3.1} \mathrm{X}_{1}+\mathrm{P}_{3.2} \mathrm{X}_{2}, \mathrm{X}_{2}=\mathrm{P}_{2.1} \mathrm{X}_{1}
$$

\subsection{Population dan Sampling}

Population of the research includes target population and reached population, that is all of Muhamadiyah Palembang Senior High School teachers. Moreover, reached population is 154 teachers from 9 Muhamadiyah Senior High School in Palembang.

Table I. Population of the Research

\begin{tabular}{clc}
\hline No. & \multicolumn{1}{c}{ School } & $\begin{array}{c}\text { The amount of } \\
\text { the teacher }\end{array}$ \\
\hline 1 & Muhammadiyah Senior High School 1 Palembang & 45 \\
2 & Muhammadiyah Senior High School 2 Palembang & 31 \\
3 & Muhammadiyah Senior High School 3 Palembang & 5 \\
4 & Muhammadiyah Senio High School 4 Palembang & 7 \\
5 & Muhammadiyah Senior High School 5 Palembang & 15 \\
\hline
\end{tabular}




\begin{tabular}{clc}
\hline 6 & Muhammadiyah Senior High School 6 Palembang & 25 \\
7 & Aisyiah Senior High Shool 1 Palembang & 17 \\
8 & Muhammadiyah Senior High School 8 Palembang & 5 \\
9 & Muhammadiyah Senior High School 9 Palembang & 3 \\
Total & $\mathbf{1 5 4}$ \\
\hline
\end{tabular}

States the methodology to determine amont of the sample uses Slovin formula; random sampling, so the sample is processed become 111 people as follow [6]: $n=\frac{N}{1+N e^{2}}$

Table 2. Sample of the Research

\begin{tabular}{clccc}
\hline No. & \multicolumn{1}{c}{ School } & $\begin{array}{c}\text { Population } \\
\text { (Teacher) }\end{array}$ & \multicolumn{2}{c}{ Sample } \\
\hline 1 & $\begin{array}{l}\text { Muhammadiyah Senior High } \\
\text { School 1 Palembang }\end{array}$ & 45 & $\frac{45}{154} \times 111$ & 33 \\
2 & $\begin{array}{l}\text { Muhammadiyah Senior High } \\
\text { School 2 Palembang }\end{array}$ & 31 & $\frac{31}{154} \times 111$ & 22 \\
3 & $\begin{array}{l}\text { Muhammadiyah Senior High } \\
\text { School 3 Palembang }\end{array}$ & 5 & $\frac{5}{154} \times 111$ & 4 \\
4 & $\begin{array}{l}\text { Muhammadiyah Senio High } \\
\text { School 4 Palembang }\end{array}$ & 7 & $\frac{7}{154} \times 111$ & 5 \\
5 & $\begin{array}{l}\text { Muhammadiyah Senior High } \\
\text { School 5 Palembang }\end{array}$ & 15 & $\frac{15}{154} \times 111$ & 9 \\
6 & $\begin{array}{l}\text { Muhammadiyah Senior High } \\
\text { School 6 Palembang }\end{array}$ & 25 & $\frac{25}{154} \times 111$ & 18 \\
7 & $\begin{array}{l}\text { Aisyiah Senior High Shool 1 } \\
\text { Palembang }\end{array}$ & 17 & $\frac{17}{154} \times 111$ & 13 \\
8 & $\begin{array}{l}\text { Muhammadiyah Senior High } \\
\text { School 8 Palembang }\end{array}$ & 5 & $\frac{5}{154} \times 111$ & 4 \\
9 & $\begin{array}{l}\text { Muhammadiyah Senior High } \\
\text { School 9 Palembang }\end{array}$ & 3 & $\frac{3}{154} \times 111$ & 2 \\
\hline Total & $\mathbf{1 5 4}$ & $\mathbf{1 1 1}$ \\
\hline
\end{tabular}

\subsection{Technique of Data Analysis}

There ae several procedures in this research as follow; (1) Data selection, checking the respondent's answer relates with the criteria; (2) determining the score of every answer; (3) analysing the data, inlcudes median averages, deviation standard, variation of each variable and (4) evaluation correlation test and regression used path analysis with softwareSPSS version 17.

In the initial analysis, the researcher used statisticical descriptive, a process to distinguish every variable independently. Whereas, statistical inferential used to evaluate hypothesis. Additionally, before hypothesis evaluation, normality and homogeneity evaluation must be finished.

Statistical descriptive is used to measure spreading or variability use deviation standard and score range.

Furthermore, label frequency and histogram graphic used path analysis before requirement analysis evaluation, that is; normality test for evry variable. Data analysis is performed significance in 0,005 . 
Goodnest of Fit evaluation from statistic model described how good and suitable becomes a set of the observation. Goodnest of fit model is done with software lisrel.

\subsection{Statistical Hypothesis}

Hypothesis of the research and formulation of the research:

1. Does pedagogical competence give direct effect toward teaching effectiveness of the teacher.

2. Does pedagogical competence give direct effect toward task commitment.

3. Does pedagogical competence give direct effect toward emotional intelligence.

4. Does emotional intelligence give direct effect toward teaching effectiveness of the teacher.

5. Does emotional inteligence give direct effect toward task commitment.

6. Does task commitment give direct effect toward teaching effectiveness of the teacher.

\section{Result Of The Research}

\subsection{Evaluation of Requirement Analysis}

Data of the research must be fulfilled evalution of requirement analysis. This research use normality test, linearity test, and significancy test as requirements analysis. Further, the evaluation of requirement analysis can be concluded as:

Table 3. the result of normality test

\begin{tabular}{|c|c|c|c|c|c|c|}
\hline \multirow{2}{*}{ No } & \multirow{2}{*}{ Regression } & \multirow[b]{2}{*}{$\mathbf{n}$} & \multirow{2}{*}{ Lcount } & \multicolumn{2}{|c|}{ L $_{\text {table }}$} & \multirow{2}{*}{ Explanation } \\
\hline & & & & $\alpha=5 \%$ & $\alpha=1 \%$ & \\
\hline 1. & $\mathrm{Y}$ to $\mathrm{X}_{1}$ & 198 & 0,0480 & 0,0841 & 0,073 & Normal \\
\hline 2. & $\mathrm{X}_{2}$ to $\mathrm{X}_{1}$ & 198 & 0,0516 & 0,0841 & 0,073 & Normal \\
\hline 3. & $\mathrm{X}_{3}$ to $\mathrm{X}_{1}$ & 198 & 0,0411 & 0,0841 & 0,073 & Normal \\
\hline 4. & $\mathrm{Y}$ to $\mathrm{X}_{2}$ & 198 & 0,0419 & 0,0841 & 0,073 & Normal \\
\hline 5. & $X_{3}$ to $X_{2}$ & 198 & 0,0525 & 0,0841 & 0,073 & Normal \\
\hline 6. & $\mathrm{Y}$ to $\mathrm{X}_{3}$ & 198 & 0,0612 & 0,0841 & 0,073 & Normal \\
\hline
\end{tabular}

\subsection{Significancy test and linearility regression}

Regression analysis used for predicted relation model, whereas correlation analysis used for reveal the effect between each variable of the research.

Table 4. Summary of significant test and linearity regression

\begin{tabular}{|c|c|c|c|c|c|c|c|}
\hline \multirow[b]{2}{*}{ Reg } & \multirow[b]{2}{*}{ Similarity } & \multicolumn{4}{|c|}{ Regression Test Linearility Test } & \multirow{2}{*}{\multicolumn{2}{|c|}{ Conclusion }} \\
\hline & & $\mathbf{F}_{\text {count }}$ & $\begin{array}{c}F_{\text {table }} \\
\alpha=0,01\end{array}$ & $\mathbf{F}_{\text {count }}$ & $\begin{array}{c}\mathbf{F}_{\text {table }} \\
\alpha=\mathbf{0 , 0 5}\end{array}$ & & \\
\hline $\mathrm{Y}$ to $\mathrm{X}_{1}$ & $\widehat{Y}=65,627+0,675 X_{1}$ & 68,87 & $6,87 * *$ & 1,390 & $1,58^{\mathrm{ns}}$ & $\begin{array}{l}\text { Significantly } \\
\text { regression }\end{array}$ & egression/Linear \\
\hline $\mathrm{Y}$ to $\mathrm{X}_{2}$ & $\widehat{Y}=59,894+0,528 X_{2}$ & 56,48 & $6,87 * *$ & 0,665 & $1,57^{\mathrm{ns}}$ & $\begin{array}{l}\text { Significantly } \\
\text { regression }\end{array}$ & Regression/Linear \\
\hline $\mathrm{Y}$ to $\mathrm{X}_{3}$ & $\widehat{Y}=37,634+0,681 X_{3}$ & 71,07 & $6,87 * *$ & 1,144 & $1,57^{\mathrm{ns}}$ & $\begin{array}{l}\text { Significantly } \\
\text { regression }\end{array}$ & Regression/Linear \\
\hline $\mathrm{X}_{3}$ to $\mathrm{X}_{1}$ & $\widehat{\mathbf{X}}_{3}=70,572+0,626 \mathrm{X}_{1}$ & 69,98 & $6,87 * *$ & 1,043 & $1,58^{\mathrm{ns}}$ & $\begin{array}{l}\text { Significantly } \\
\text { regression }\end{array}$ & Regression/Linear \\
\hline
\end{tabular}




\begin{tabular}{llllllll}
\hline $\mathrm{X}_{3}$ to $\mathrm{X}_{2}$ & $\widehat{\mathbf{X}}_{\mathbf{3}}=\mathbf{6 7 , 2 4 8}+\mathbf{0 , 4 7 2} \mathbf{X}_{\mathbf{2}}$ & 51,41 & $6,87^{* *}$ & 1,049 & $1,57^{\mathrm{ns}}$ & $\begin{array}{l}\text { Significantly } \\
\text { regression }\end{array}$ & Regression/Linear \\
$\mathrm{X}_{2}$ to $\mathrm{X}_{1}$ & $\widehat{\mathbf{X}}_{\mathbf{2}}=\mathbf{6 7 , 6 1 4}+\mathbf{0 , 5 7 4} \mathbf{X}_{\mathbf{1}}$ & 32,34 & $6,87^{* *}$ & 0,978 & $1,58^{\text {ns }}$ & $\begin{array}{l}\text { Significantly } \\
\text { regression }\end{array}$ & Regression/Linear \\
\hline
\end{tabular}

Explanation : ** : Significantly Regression : Non significant (linear regression)

\subsection{Hypothesis Evaluation}

\section{Goodnest of Fit Test}

Model evaluation is needed as a process to determine hypothetical model is consistence with empirical data. Furthermore, it can be done by comparing theoretical matrix with correlation empiric, based on output result with Lisrel, in "Goodness-of-Fit Statistics" the statistical model evaluation as follows:

\section{Goodness-of-Fit Statistics}

Degrees of Freedom for (C1)-(C2)

Maximum Likelihood Ratio Chi-Square (C1) Browne's (1984) ADF Chi-Square (C2_NT)
0

$$
\begin{aligned}
& 0.0(\mathrm{P}=1.0000) \\
& 0.0(\mathrm{P}=1.0000)
\end{aligned}
$$

The Model is Saturated, the Fit is Perfect !

Based on the recapitulation table, it can be concluded that Chi-square $=0,0$ with degree $=$ 0 and $\mathrm{p}=1$, therefore $\mathrm{p}=1>0,50$ or there is no significantly between theoretically correlation and empirical correlation matrix. It means that H0 is accepted, the model is suitable with empirical data so fit model is classified well.

\subsection{Path Coefficient}

\begin{tabular}{|c|c|c|c|c|c|c|}
\hline \multirow{2}{*}{ No. } & \multirow{2}{*}{$\begin{array}{l}\text { Direct } \\
\text { Effect }\end{array}$} & \multirow{2}{*}{$\begin{array}{c}\text { Path } \\
\text { Coeffecient }\end{array}$} & \multirow{2}{*}{ dk } & \multirow{2}{*}{$\mathbf{T}_{\text {count }}$} & \multicolumn{2}{|c|}{$\mathbf{t}_{\text {table }}$} \\
\hline & & & & & $\alpha=0,05$ & $\alpha=0,01$ \\
\hline 1 & $\mathrm{X}_{1}$ toward $\mathrm{Y}$ & 0,320 & 107 & 3,70 & 1,98 & 2,62 \\
\hline 2 & $\mathrm{X}_{2}$ toward $\mathrm{Y}$ & 0,278 & 107 & 3,40 & 1,98 & 2,62 \\
\hline 3 & $\mathrm{X}_{3}$ toward $\mathrm{Y}$ & 0,271 & 107 & 2,94 & 1,98 & 2,62 \\
\hline 4 & $\mathrm{X}_{1}$ toward $\mathrm{X}_{3}$ & 0,460 & 108 & 5,84 & 1,98 & 2,62 \\
\hline 5 & $\mathrm{X}_{2}$ toward $\mathrm{X}_{3}$ & 0,346 & 108 & 4,40 & 1,98 & 2,62 \\
\hline 6 & $\mathrm{X}_{1}$ toward $\mathrm{X}_{2}$ & 0,478 & 109 & 5,69 & 1,98 & 2,62 \\
\hline
\end{tabular}

Table 5. Summary of path significantly test

The structural diagram can be seen as follows: 


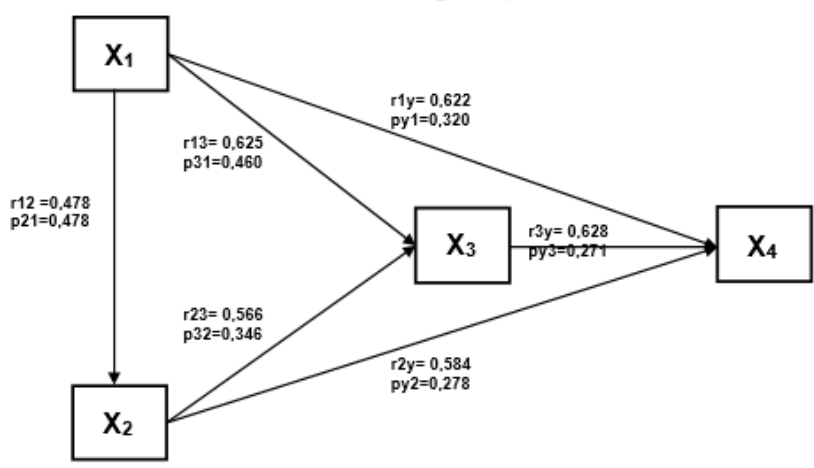

Fig. 2. Diagram Effect of Causal Path $\mathrm{X} 1, \mathrm{X} 2$ and $\mathrm{X} 3$ toward $\mathrm{Y}$

\section{Discussion of the research}

Based on path analysis, hypothesis evaluation process can be concluded in table 4.4 as follows:

Table 6. Summary of hypothesis evaluation result

\begin{tabular}{lcccl}
\hline Direct Effect & $\begin{array}{c}\text { Path } \\
\text { Coefficient }\end{array}$ & $\mathbf{T}_{\text {count }}$ & $\mathbf{t}_{\text {table }}$ & \multicolumn{1}{c}{ Final Result } \\
\hline $\mathrm{X}_{1}$ toward Y & 0,320 & 3,70 & 2,62 & $\begin{array}{l}\mathrm{H}_{0} \text { is rejected, } \mathrm{H}_{1} \text { is accepted. There is } \\
\text { positive direct effect from } \mathrm{X}_{1} \text { toward } \mathrm{Y}\end{array}$ \\
$\mathrm{X}_{2}$ toward Y & 0,278 & 3,40 & 2,62 & $\begin{array}{l}\mathrm{H}_{0} \text { is rejected, } \mathrm{H}_{1} \text { is accepted. There is } \\
\text { positive direct effect from } \mathrm{X}_{2} \text { toward } \mathrm{Y}\end{array}$ \\
$\mathrm{X}_{3}$ toward Y & 0,271 & 2,94 & 2,62 & $\begin{array}{l}\mathrm{H}_{0} \text { is rejected, } \mathrm{H}_{1} \text { is accepted. There is } \\
\text { positive direct effect from } \mathrm{X}_{3} \text { toward } \mathrm{Y}\end{array}$ \\
$\mathrm{X}_{1}$ toward $\mathrm{X}_{3}$ & 0,460 & 5,84 & 2,62 & $\begin{array}{l}\mathrm{H}_{0} \text { is rejected, } \mathrm{H}_{1} \text { is accepted. There is } \\
\text { positive direct effect from } \mathrm{X}_{1} \text { toward } \mathrm{X}_{3} \\
\mathrm{H}_{0} \text { is rejected, } \mathrm{H}_{1} \text { is accepted. There is } \\
\text { positive direct effect from } \mathrm{X}_{2} \text { toward } \mathrm{X}_{3} \\
\mathrm{H}_{0} \text { is rejected, } \mathrm{H}_{1} \text { is accepted. There is } \\
\text { positive direct effect from } \mathrm{X}_{1} \text { toward } \mathrm{X}_{2}\end{array}$ \\
$\mathrm{X}_{2}$ toward $\mathrm{X}_{3}$ & 0,346 & 4,40 & 2,62 & 2,62 \\
$\mathrm{X}_{1}$ toward $\mathrm{X}_{2}$ & 0,478 & 5,69 & 2, & \\
\hline
\end{tabular}

Based on data analysis and hypothesis evaluation, the result will be dedcribed as follows:

\subsection{Direct Positive Effect of Pedagogical Competence toward teaching effectiveness}

Hypothesis result shows that pedagogical competence has significant effect toward teaching effectiveness with coefficient score 0,586 and coefficient path 0,320 . It means that pedagogical competence has significantly positive effect toward teaching effectiveness. Teacher not only mastering basic concept and discipline procedure but also pedagogical content, such as; analogy, illustration, sample and demonstration. Moreover, teacher has an important duty, not only for teaching the students but also increasing educational level. Pedagogical competence of the teachers become an important factor to achieve teaching effectiveness. 


\subsection{Direct Positive effect of pedagogical competence toward emotional intelligence}

Hypothesis result shows that pedagogical competence has significantly effect toward emotional intelligence. The score of coefficient correlation is 0,478 and coefficient path is 0,478 . It means that pedagogical competence has significantly positive effect toward emotional intelligence.

Furthermore, it is related with the previous research about self learning toward [5],"Leadership, Emotional Intelligence and Employee Engagement: Creating a Pedagogic Competence"in 2000. He states that a relation between leadership, emotional intelligence, employee's commitment will create emotional intelligence of the teacher in order to increase pedagogical competence of the teacher.

\subsection{Direct Positive effect of pedagogical competence toward task commitment}

Hypothesis result shows that leadership effectiveness of the headmaster has significantly effect toward task commitment. The cooefficient correlation score is 0,446 and coefficient path is 0,460 . It means that pedagogical competence has positive effect toward task commitment.

\subsection{Direct Positive of emotional intelligence toward teaching effectiveness}

Hypothesis result shows that emotional intelligence has significantly positive effect toward teaching effectiveness. The cooefficient correlation score is 0,473 and coefficient path score is 0,278. It means that emotional intelligence has positive effect toward teaching effectiveness.

Thus, emotional intelligence, teachers will be able to motivate the student, to control teachers' emotion and to build good relation with the students, as a result High emotional intelligence will create effective teaching proccess.

\subsection{Direct Positive of emotional intelligence toward task commitment}

Hypothesis result shows that emotional intelligence has significantly positive effect toward task commitment. Coefficient correlation score is 0,416 and coefficient path score is 0,346. Itn meas that emotional intelligence has positive effect toward task commitment.

Meanwhile, Randall, Fedor, and Longenecker (in Greenberg \& Baron, 1993) state that commitment of organization related with High desire to share and to sacrifice for organization.

\subsection{Direct Positive effect of task commitment toward teaching effectiveness}

Hypothesis result shows that task commitment has significantly positive effect toward teaching effectiveness. The cooefficient correlation score is 0,271 . It means that task commitment has positive effect toward teaching effectiveness.

Job's commitment or teachers' desire Komitmen kerja atau keinginan guru within their performance as teachers have responsibility to the students, it means that teachinh effectiveness of the teachers affect the students' development during learning process. indeed, teachers who have strong commitment will create effectiveness in the teaching process. 


\section{Conclusion And Implication}

\subsection{Conclusion}

Based on data analysis in the previous chapter, the research can be concluded with several poins as follow:

1. There is direct effect of pedagogical competence $\left(\mathrm{X}_{1}\right)$ toward teaching effectiveness of the teacher $(\mathrm{Y})$ it means that if pedagogical competence is increased, teaching effectiveness of the teacher will be more effective so the purpose in leraning process can be achieved.

2. There is direct effect of pedagogical competence $\left(X_{1}\right)$ toward emotional intelligence $\left(X_{2}\right)$ it means that teachers who have pedagogical competence will be able to understand, to control their emotion and to motivate the students during learning process.

3. There is direct effect of pedagogical competence $\left(X_{1}\right)$ toward task commitment $\left(X_{3}\right)$ it means that teachers who have pedagogical competence will have more commitment and reponsibility as a teacher.

4. There is direct effect of emotional intelligence $\left(\mathrm{X}_{2}\right)$ toward teaching effectiveness of the teacher $(\mathrm{Y})$, it means, teachers have positive relation with their student so the teachers will be able to motivate the students in their learning process effectively.

5. There is direct effect of emotional intelligence $\left(X_{2}\right)$ toward task commitment $\left(X_{3}\right)$ it means, teachers who have emotional intelligence will have a strong commitment, thus will increase task commitment of the teacher in teaching process.

6. There is direct effect of task commitment (x3) toward teaching effectiveness of the teacher (Y) it means that task commitment determined teacher effcetiveness in the teaching process.

\subsection{IMPLICATION}

Indeed, based on the previous conclusion, six hypotheses are accepted, these show that methodology, media, determine every steps of learnin process, and evaluate resut of the research to increase Task Commitment and Teaching Effectiveness of Muhammadiyah Palembang Senior High School can be done by increasing the task commmitment of the teacher.

\section{References}

[1] T. Ryegard, A., Apeigren, K. \& Olsson, "A Swedish Perspective on Pedagigical Com petence," 2010.

[2] S. L. \& M. A. V. G. McShane, Organizational Behavior. Boston: McGraw-Hill Irwin, 2008.

[3] R. B. Sumarsono, Jumal. Universitas Negeri Malang: Manajemen Pendidikan Malang, 2012.

[4] A. dan Rajak, Komitmen dalam Bekerja. Semarang: CV Aneka Ilmu, 2007.

[5] L. Nowack, "Emotional Intelhgence and Emçicee Engagement: Creating a Pedagogic Competence," Intemational J. Educ. Res., vol. 5, 2007.

[6] S. G. Consuelo, Research Methodology. Jakarta: Printing Company Onezoncity., 2007. 